\title{
Organ Transplant Trade: A Moral Examination
}

\author{
Seeiso J. Koali \\ Department of Philosophy, National University of Lesotho, Roma, Lesotho \\ Email: koaliseeiso@yahoo.com
}

Received 17 March 2015; accepted 14 April 2015; published 15 April 2015

Copyright (C) 2015 by author and Scientific Research Publishing Inc.

This work is licensed under the Creative Commons Attribution International License (CC BY). http://creativecommons.org/licenses/by/4.0/

(c) (i) Open Access

\begin{abstract}
This article normatively discusses two moral theories namely: Ubuntu and Deontology, with the aim of arguing against the practice of organ transplant trade. It is argued that this practice violates a rule of categorical imperative which states that human beings should not be used as the means, but always be treated as ends into themselves. Organ transplant trade also affects negatively the process of informed consent of vulnerable people who may overlook the risks in trading of organs and focus only on the monetary incentives. This article is based on non-empirical research which employs the method of critical and conceptual analysis with a review of existing literatures on the subject. Therefore, this article addresses the following question: do people have ownership of their bodily parts to an extent that they can autonomously sell them to make a living? This question is answered by concluding that the upholding of moral duties of human beings eliminates all human acts that violate the notion of human dignity.
\end{abstract}

\section{Keywords}

Autonomy, Deontology, Informed Consent, Organ Transplant Trade, Ubuntu, Vulnerability

\section{Introduction}

The issue of ownership regarding human organs and autonomy raises vexing issues in bioethics. Logically, ownership connotes that human beings are entitled to sell their organs in order to fight poverty. Due to worldwide shortage of organs available for transplantation, other human beings may feel inclined to exercise their autonomy and choose commercial trade in human organs. However, in this article, it is argued that the life of a human being is sacrosanct and dignified to an extent that it cannot be used as a commodity because in this way, human beings will be treated like mere objects that have price. This practice also compromises the element of informed consent in medical procedures, because vulnerable individuals (poor people) will be attracted to sell 
their organs in order to make a living without focusing much on the risks ratio.

This article normatively discusses two moral theories namely, Ubuntu as an African moral theory and Deontology against the practice of organ transplant trade. This article also discusses the rule of categorical imperative which states that human beings should never be used as the means to an end. It is argued that trading of human organs fails to show respect to the intrinsic human dignity of human beings, and the same practice can promote human trafficking due to greed whereby people will be tempted to make more money by forcing others to sell their organs.

The discussion on deontology will be mainly on the rules of categorical imperative. While in a typical African ethic, the only way to develop one's humanness is to relate to others in a positive way. One becomes a person solely through other persons, which means that one cannot realize one's true self in opposition to others or even in isolation from. According to Ubuntu, only actions that promote the harmonious relationship of the communal members are deemed to be good and acceptable. While actions like trading of human organs are deemed to demean the dignity of the human being and therefore, such actions should not be practiced.

\section{The Practice of Organ Transplant Trade}

While it is commonly believed that trafficking only takes place for commercial sexual exploitation or for forced labour, trafficking in fact takes many forms such as trafficking for forced marriage and trafficking for organ trade among others. "An organ transplant is the transplantation of a whole or partial organ from one body to another, for the purpose of replacing the recipient's damaged or failing organ with a working one from the donor site” (Glannon, 2005: p. 155). However, some scholars argue for the organ transplant trade due to the high rate of a devastating shortage of organs and a growing number of patients on the waiting list of the organs.

Figure 1 shows people who freely practice organ transplant trade in Iran in order to make money and reduce the high rate of people on the waiting list. In addition, this figure depicts that the proponents of organ trade do not regard this practice as being unethical or unlawful because they are doing it autonomously. However, some other scholars consider this practice to be the cause of trafficking for organs trade which is a crime that occurs in three broad categories. According to (Mackellar, 2014: p. 64), there are cases where traffickers force or deceive the victims into giving up an organ. There are cases where victims formally or informally agree to sell an organ and are cheated because they are paid for the organ or are paid less than the promised price. Thirdly, vulnerable persons are treated for an ailment, which may or may not exist and thereupon organs are removed without the victim's knowledge.

However, some other people see trafficking of organs trade as a good mechanism to be used to reduce a number of people on the waiting list. Those promoting the implementation of a regulated system for the payment for organs indicate that it may save the lives of persons on waiting lists since it represents the only means by which a greater number of individuals in society can be encouraged to consider providing an organ. An example of such a system for kidneys has already "been in existence in Iran since the late 1980s, which is the only regulated organ payment programme in the world” (Mackellar, 2014: p. 55). In addition, after the transplantation, the person providing the kidney is compensated by both the government and the person receiving the kidney. This represents about US \$3000 of which about US \$600 is paid by the government (Hippen, 2005: p. 594).

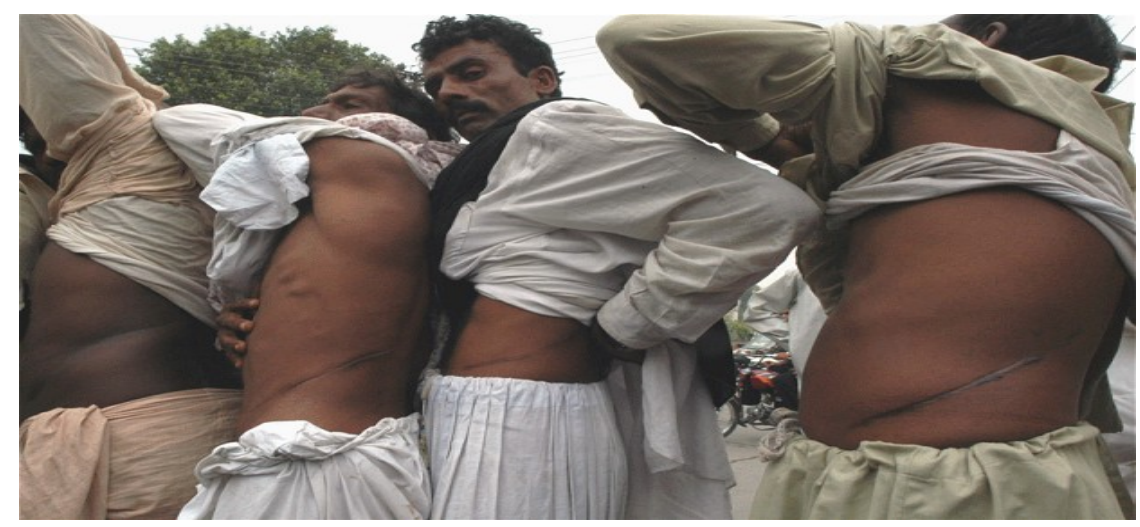

Figure 1. People who freely practice organ transplant trade in Iran. 
The proponents of organ transplant trade also argue that the implementation of a regulated system of payment for organs would, it is claimed, "substantially address the unregulated exploitation of vulnerable groups through organ trafficking since the demand for organs would be reduced. Studies from the World Health Organization indicate that about 7000 kidneys each year are illegally obtained by traffickers around the world” (Hippen, 2005: p. 596). In addition, Hippen also argues that illegal deals in Pakistani donors are offered around US $\$ 2500$ for a kidney but receive only about half the amount because middlemen take a large cut. Thus, it is suggested that a regulated market for organs would considerably address such abuse if, for example, a government institution could actually buy the organs from the individuals so that appropriate regulation and care should be provided to both the seller and the recipient.

The motives from this practice emanate from the act utilitarianism which views actions to be morally acceptable if and only if they produce good results for many. With all these, it means that those who need organs will be helped and more people will get organs through organ trade formation, there will be no exploitation for those who are vulnerable (the poor) because there would be a very low rate of organs shortage. In other words, "for other people, a financial incentive will help to match supply and demand thereby addressing the shortage of organs and other tissues” (Dhai \& MacQuoid-Mason, 2011: p. 119).

Some other arguments for the practice of organ transplant trade are based on the principle of autonomy which refers to "self-rule that is free from both controlling interference by others and from limitations, such as inadequate understanding, that prevent meaningful choices” (Beauchamp \& Childress, 2001: p. 58). As ethicist, Julian Savulescu indicates that people have a right to make a decision to sell a body part (Savulescu, 2003: p. 648). According to him, human beings are entitled to ownership of their bodies. Thus, they ought not to be paternalised, but they should be allowed to sell their organs and live a better life with the income they will get from the market.

\section{Ubuntu as a Moral Theory in Organ Transplant Trade}

The maxim of Ubuntu states that; umuntu ngumuntu ngabantu/motho ke motho ka batho. These are, respectively, Zulu and Sotho versions of a traditional African aphorism, often translated as: "a person is a person through other persons” (Ramose, 1999: p. 49; Shutte, 1993: p. 46). Under the light of Ubuntu's moral theory, a human being has a chance to fail to attain botho which can be translated to mean humanness. For example, those who perform immoral acts such as killing, raping, stealing, disrespecting others are described as lacking the status of botho. The moral theory of Ubuntu emphasizes that the only way to develop one's humanness is to relate to others in a positive way. "One becomes a person solely through other persons, which means that one cannot realize one’s true self in opposition to others or even in isolation with them” (Metz \& Gaie, 2010: p. 275). Under the guidance of Ubuntu, sub-Saharans do not consider themselves as hermits, but as beings that are communally integrated with one another regardless of their different status and positions in life.

The exhibition of Ubuntu/botho (humanness) that can help one to develop well can be done in a communitarian background whereby an individual recognizes his character together with other's characters. Shutte (1993: p. 30) argues that "our deepest moral obligation is to become more fully human. This means entering more and more deeply into community with others." Caring and respecting other human beings reflect the elements of Ubuntu in a way that immoral actions that may negatively affect other people's welfare are prohibited. For example, people who disrespect those who are severely mentally retarded, diminish these people's personhood in their communities because their actions would be perceived as lacking the aspect of Ubuntu/botho.

Just like in Kantian moral theory of deontology whereby an action is morally acceptable if it is in conformity with the categorical rules, Ubuntu does the same job through its maxim umuntu ngumuntu ngabantu. Metz (2010: p. 51) explicitly argues that:

An action is right just insofar as it is a way of living harmoniously or prizing communal relationships, ones in which people identify with each other and exhibit solidarity with one another, otherwise an action is wrong.

To identify with each other "is largely for people to think of themselves as a 'we': while to exhibit solidarity with one another is mainly for people to engage in mutual aid, to act for the sake of one another, to seek to improve some other organisms’ quality of life for non-instrumental motives” (Metz, 2012: p. 393). The solidarity and identification that Metz has highlighted maybe seen as the force of attraction that keeps the harmonious re- 
lationships alive among sub-Saharans. This harmonious relationship becomes vivid when people respect and care for other people. This maxim encourages only the positive relationships that show respect to others regardless of their mental status. People such as sorceries or witches do not qualify for the status of Ubuntu because of their unacceptable actions that cause pain, sorrow and deaths of other people. Hence, those that do not relate positively with others are said to lack botho and they are often described as animals.

Harmony is achieved through close and sympathetic social relations within the group. This, however, implies that the common good of caring and loving one another can be attained through communal relationships. On this issue, Mbiti (1969: p. 108) also says, “I am because we are and since we are, therefore I am.” This statement refers to the promotion of the harmonious belongingness among the societal members without neglecting other human beings. Ubuntu is similar to virtue ethics in a sense that virtue ethics is concerned with a person's motivation for action, the disposition or character from which the action issues, instead of with features of action itself. Actions are evaluated as expressions of the agent's disposition or character. If one performs a compassionate act, for example, it is because one has a compassionate disposition to act in that way. On this issue, ubuntu as a moral theory will say that "when we want to give high praise to someone in sub-Saharan morality we say: Hey, so-and-so has ubuntu. Then you are generous, you are hospitable, you are friendly and caring and compassionate. Anger, resentment, lust for revenge, even success through aggressive competitiveness, are corrosive of this good” (Tutu, 1999: pp. 31-35). Ubuntu and virtue ethics consider the actions of human beings from their inner moral character and their inner motivation behind their actions. Just like ubuntu, "virtue ethics is agent based rather than action based. It is concerned with a person's motivation for action, the disposition or character" (Glannon, 2005: pp. 13-14).

\section{Ubuntu against Organ Transplant Trade}

Through the lens of Ubuntu, the practice of organ transplant trade fails to promote the notion of personhood that is acquired through virtuous actions. In the sub-Saharan Africa this practice will demean human beings into the level of animals that can be used as commodities. Ubuntu only encourages positive relationships that will show respect to humanity as a whole within the communities. Caring and respecting other human beings reflect the elements of Ubuntu in a way that immoral actions that may negatively affect other people's welfare are prohibited.

The practice of organ transplant trade is very detrimental to other members of the community because it is likely to promote human trafficking to the extent that other human beings can be forced to trade their organs. For this reason, it is common to find people wearing or hanging all sorts of objects believed to contain the vital power around their wrists, waists, necks or arms in traditional African communities. For the same reason, others engage in ritual murders in order to enhance their power, respect, and maximize profit within their societies. They act without a sense of moral accountability as relates to the consequences of the actions they choose to carry out as long as they can justify their cause as having been driven by a "temptation" inherent in financial markets. A greedy person is certainly one who cannot "bridle" his desire to acquire more returns no matter what the consequences are as long as the probability of "making a kill” is high enough to make the act tempting.

Converse to this line of argument, this paper argues that any society that instills in their offspring that greed is morally bad would produce financial market players that act in a way that reflects their abomination of greed. This can further be deepened by the church, moral law, school and the literature that promote the same standard of morality. Hence, society will produce individuals with a particular moral fibre, and these become players in markets for good or bad depending on the type of moral ethos cultivated by social institutions in these individuals. This paper sees moral value as an important input in enabling financial market fundamentals to function properly for the good of the entire society. Morality can be institutionally inculcated into the very fibre of humanity for the good of humanity. For example, a person who does not relate harmoniously with other people in a community diminishes his or her personhood, and s/he is said to lack botho/humanness.

Ubuntu is different from act utilitarianism because according to the latter actions are to be judged right or wrong solely by virtue of their consequences; nothing else matters. In assessing consequences, the only thing that matters is the amount of happiness or unhappiness that is created. For those who support act utilitarianism, the practice of organ transplant trade will be acceptable because it will produce good results for many. However, Ubuntu does not focus on the end results alone, but it also focuses on the inner moral character of the individual within their own communities. Thus, harmony is achieved through close and systematic social relations within 
the group. Individuals consider themselves as integral parts of the whole community, and a person is socialized to think of himself or herself, as inextricably bound to others. Ubuntu ethics can be termed anti-egoistic as it discourages people from seeking their own good without regard for, or to the detriment of others and the community.

In a medical research setting, it will be virtuous for the researchers not to deceive their participants and give them enough time to consent autonomously without anyone coercing them. Virtue ethics and deontology in this regard will consider that action as morally acceptable because it is based on the justifiable means. Ubuntu will also agree with this implication but it will differ from these two moral theories because it goes deeper than them. That is, “once a researcher and a participant have begun to think of themselves as 'we' engaged in the joint project of testing a vaccine, they share a way of life that imposes special obligations to care for one another's quality of life that can go beyond those listed in a contract” (Metz, 2010: p. 56).

In African societies, emphasis is put on the communitarian relationships that bound all the members of the society. For Menkiti, there are three inferences that give individuals human dignity within their own communities. Firstly, in the African view "it is the community which defines the person as person, not some isolated static quality of rationality, will, or memory; secondly, that the African view supports the notion of dignity/seriti as acquired not merely granted as a consequence of birth; thirdly, that as far as African societies are concerned, dignity is something at which individuals could fail” (Menkiti, 1984: p. 173). These claims made by Menkiti demonstrate that dignity in an African thought is acquired in the communal participation and a person becomes a full person in the eyes of the community after the incorporation. Human beings develop their social moral actions better in an integrated communal world which is where they can learn to respect the dignity of other people.

\section{Deontology as a Moral Theory}

This section discusses the moral theory of deontology which was found by Immanuel Kant, while the next section discusses the arguments against the practice of organ transplant trade. Deontology is a duty based moral theory because it argues that people should always perform their duties: It includes respect for a moral law such as lying is always bad. According to this moral theory, human beings should always use justifiable means to attain their end results. Immanuel Kant argues for the human dignity of human beings and he analyzed that worth as inherently embedded within human beings because "of an endowment with reason, a reasoning power that enables them to exercise their autonomy and to follow the moral laws” (Kant, 1996: p. 186).

In addition to his argument, Beauchamp \& Childress see personal autonomy as a "self-rule that is free from both controlling interference by others and from limitations, such as inadequate understanding, that prevent meaningful choices” (Beauchamp \& Childress, 2001: p. 58). Autonomy in this regard can be seen on individuals who do their moral duties according to the demands of moral rules and principles. For Kant, it is morally wrong however for other human beings to make false promises to others, because such actions use other human beings as the means to an end, as well as violating their human worth.

Kantianism states that a moral action is one done out of duty, a duty based on pure practical reason. This duty or categorical imperative views humanity as an end and "never as a means" to an end. Actions that have a social benefit such as voluntary exchange in a free market are justified if such action benefits both parties regardless of the differences in the information that each party may have. It is the moral duty of the party with more information not to use the additional information to take advantage of the other party. This is also what Immanuel Kant argued when he contrasted "dignity” with "price” indicating that: "Everything has either a price or a dignity. If it has a price, something else can be put in its place as an equivalent; if it is exalted above all price and so admits of no equivalent, then it has a dignity” (Kant, 1996: p. 105). In other words, something with a price has worth that can be measured against other things and rated for value. On the other hand, something with inherent human dignity has absolute worth, making it the ultimate value.

\section{Deontology against Organ Transplant Trade}

Through the lens of deontology, the payment of human organs is considered to be immoral because it uses human beings as the means or as commodities for others to earn their living. This kind of incentives can also deteriorate our human dignity into the level of commodities because other human beings will practise organ trafficking. Kant argues that we ought to "act so that we treat humanity, both in our own person and in that of another, always as an end and never merely as a means. The value of human beings is beyond all price” (Kant 
quoted in Rachels, 2007: p. 131). This means that human beings are not supposed to be used as commodities that have prices.

For Kant, human beings have an intrinsic human dignity, while other things have value that can help human beings to reach their end results. In relation to organ transplant trade, human beings are allowed to donate their organs autonomously and out of altruism with the motive of promoting the welfare of others which is demanded by the principle of beneficence. Monetary influence will make others to be greedy and lead them to practise organ trafficking. Hence, financial incentives may also "interferes with the consent process” (Dhai \& McQuoidMason, 2011: p. 119). Some people may consent too quickly to donate their organs mainly because they are desperately in need of some money without considering the risks that are likely to follow after they have been paid.

The prohibition of payments for organ donations is very fundamental because the least-off people and those who are vulnerable such as the children, elderly people, and severely mentally retarded people may be abused for cash. That is, "the poor and vulnerable may find themselves tempted by the financial incentives and thereby ignore the risks” (Dhai \& McQuoid-Mason, 2011: p. 119). In this regard, deontology prohibits all the actions or practices that use human beings like commodities.

The South African law regarding payment for organ donations under section 60 (4) of the National Health Act 61 of 2003 maintains that it is an offence for a person who has donated tissue, a gamete, blood or a blood product to receive any form of financial or other reward for such donation, except for the reimbursement of reasonable costs incurred by him or her to provide such donation; it is also an offence for a person to sell or trade in tissue, gametes, blood or blood products. On the same practice, organ transplant trade is presently illegal in Singapore. Under the Human Organ Transplant Act of 2009, (section 14 (s2)) it is stated that "it is a criminal offence to enter into a contract or agreement on the sale or supply of any organ or blood” (Lim, 2008: p. 2). The Singaporeans advocate for legalizing organ trading in pointing to the waiting list of about 600 people who would die without a transplant. "The average waiting time is currently nine years for a kidney. They felt that ethical concerns should not hinder any policy review that might help to save lives and reduce shortages that promote a black market for organs” (Lim, 2008: p. 3).

\section{Mental Competence and Vulnerability}

The practice of organ transplant trade may also affect one's mental competence and autonomy in a sense that the seller mainly focuses on the end results (incentives) rather than also focusing much attention on the risks that are likely to follow from that practice. According to Buchanan \& Brock (1989: p. 18), "Competence is to be understood as decision-making capacity.” Competence is decision-relative, not global, because a patient may be competent to make a particular decision at a particular time, under certain circumstances, but incompetent to make another decision or even the same decision, under different conditions. A person is usually considered to be mentally competent if able to understand a therapeutic or research procedure, to deliberate regarding its major risks and benefits, and to make a decision in light of this deliberation.

Vulnerability is one of the causes of mental incompetence. For example, people who lack money to buy food, lack of adequate housing, may opt for the practice of organ transplant trade as a way of fighting poverty without proper consideration of the risks that may be caused on their welfare. Dhai (2013: p. 45) classifies such people under allocational vulnerability which refers to the population that is disadvantaged. Such populations live in poverty, without food, clean water, sanitation, electricity, adequate housing and access to health care.

The question is: should vulnerable people dying with hunger be allowed to sell their organs in order to fight poverty? Through the lens of utilitarianism which says an action is good if it maximizes good for many people, organ transplant trade will be perceived as a morally good practice because many vulnerable people will be able to improve their style of living. For this moral theory, the end results justify the means. However, through the moral theory of deontology which this paper supports, such an action will be immoral because it fails to treat human beings as ends into themselves; rather it treats human beings as the means to attain the end results. Vulnerable people should not be exploited by being allowed to be engaged into the practices that will pose harm to their welfare.

Therefore, it is very imperative to compare Ubuntu as an African moral theory with the Western moral theory of deontology in the medical practices like organ transplant trade. Ubuntu in this case raises an alarm that organ trade is not reflecting our communal humanness because people can end up in ritual killings because they want to sell other people's organs. Such actions in our African world view, especially through Ubuntu are deemed to be against the maxim of Ubuntu which promotes harmonious relationships among societal members. 


\section{Conclusion}

In this article, it is argued that deontology through its rules of categorical imperative rejects the practice of organ trade because the intrinsic human dignity of human beings is priceless. Thus, since selling of organs goes together with price tags, according to deontology such actions are morally wrong because they use human beings as the means to an end. Ubuntu as a moral theory in the African worldview also rejects organ transplant trade because it uses unjustifiable means by using human beings like objects to be sold. According to Ubuntu, this practice violates the personhood of human beings which through it, all immoral practices that may end up promoting actions like (liretlo) which is translated to mean ritual killings of human beings, are prohibited. For Ubuntu, an action is morally bad if it does not promote the harmonious relationship among the societal members. Greed is part of a human character; hence, vulnerable human beings like mentally disabled, as well as children can be forced by greedy people to sell their organs.

\section{References}

Beauchamp, T., \& Childress, J. (2001). Principles of Biomedical Ethics. New York: Oxford University Press.

Buchanan, A. E., \& Brock, D. W. (1989). Deciding for Others, the Ethics of Surrogate Decision Making. New York: Cambridge University Press.

Dhai, A., \& McQuoid-Mason, D. (2011). Bioethics, Human Rights and Health Law, Principles and Practice. Cape Town: Juta and Company Ltd.

Dhai, A. (2013). Practical Ethics Guide for Researchers and Research Ethics Committee Members. Steve Biko Centre for Bioethics.

Glannon, W. (2005). Biomedical Ethics. New York: Oxford University Press.

Hippen, B. E. (2005). In Defense of a Regulated Market in Kidneys from Living Vendors. Journal of Medicine and Philosophy, 30, 593-626. http://dx.doi.org/10.1080/03605310500421397

Kant, E. (1996). The Metaphysics of Morals. New York: Cambridge University Press. http://dx.doi.org/10.1017/CBO9780511809644

Lim, M. K. (2008). Legalization of Organ Trade. Singapore City: National University of Singapore.

MacKeller, C. (2014). Human Organ Markets and Inherent Human Dignity. Scottish Council on Human Bioethics, 20 , 53-71. http://dx.doi.org/10.1179/2050287714Z.00000000043

Menkiti, I. (1984). Person and Community in African Traditional Thought. In R. Wright (Ed.), African Philosophy, an Introduction. Lanham, MD: University Press of America.

Mbiti, J. (1969). African Religions and Philosophy. Oxford: Heinemann Educational Books.

Metz, T. (2010). African and Western Moral Theories in a Bioethical Context. Developing World Bioethics, 10, 49-58. http://dx.doi.org/10.1111/j.1471-8847.2009.00273.x

Metz, T., \& Gaie, J. (2010). The African Ethic of Ubuntu/Botho: Implications for Research on Morality. Journal of Moral Education, 39, 273-290. http://dx.doi.org/10.1080/03057240.2010.497609

Ramose, M. (1999). African Philosophy through Ubuntu. Harare: Mond Books.

Rachels, J. (2007). The Elements of Moral Philosophy (5th ed.). Boston, MA: McGraw Hill.

Shutte, A. (1993). Philosophy for Africa. Rondebosch: University of Cape Town Press.

Savulescu, J. (2003) No Consent Should Be Needed for Using Leftover Body Material for Scientific Purposes. British Medical Journal, 325, 648-651.

Tutu, D. (1999). No Future without Forgiveness. New York: Random House. 